\title{
CHEAP TALK? STRATEGY PRESENTATIONS AS A FORM OF CHIEF EXECUTIVE OFFICER IMPRESSION MANAGEMENT
}

\begin{tabular}{|r|l|}
\hline Journal: & Strategic Management Journal \\
\hline Manuscript ID & SMJ-14-13422.R4 \\
\hline Wiley - Manuscript type: & Research Article \\
\hline Keywords: & $\begin{array}{l}\text { impression management, new CEOs, strategy presentations, event study } \\
\text { methodology, voluntary disclosures }\end{array}$ \\
\hline Abstract: & $\begin{array}{l}\text { We develop and test a set of hypotheses on investors' reactions to a } \\
\text { specific form of impression management, public presentations of overall } \\
\text { strategy by Chief Executive Officers (CEOs). Contrary to expectations from } \\
\text { a 'cheap talk' perspective, we suggest that such strategy presentations } \\
\text { convey valuable information to investors, especially in conditions of } \\
\text { heightened information asymmetry associated with varying types of new } \\
\text { CEOs. Broad empirical support for our theoretical arguments is shown in a } \\
\text { sample of strategy presentations carried out by NYSE and NASDAQ listed } \\
\text { organizations over 10 years. Our research contributes to literature on new } \\
\text { CEOs and impression management. We draw out implications both for } \\
\text { management and for further research. }\end{array}$ \\
\hline
\end{tabular}




\title{
CHEAP TALK? STRATEGY PRESENTATIONS AS A FORM OF CHIEF EXECUTIVE OFFICER IMPRESSION MANAGEMENT
}

\begin{abstract}
Research Summary:
We develop and test a set of hypotheses on investors' reactions to a specific form of impression management, public presentations of overall strategy by Chief Executive Officers (CEOs). Contrary to expectations from a 'cheap talk' perspective, we suggest that such strategy presentations convey valuable information to investors, especially in conditions of heightened information asymmetry associated with varying types of new CEOs. Broad empirical support for our theoretical arguments is shown in a sample of strategy presentations carried out by NYSE and NASDAQ listed organizations over 10 years. Our research contributes to literature on new CEOs and impression management. We draw out implications both for management and for further research.
\end{abstract}

\section{Managerial Summary:}

We examine the impact of public presentations on company strategy by Chief Executive Officers (CEOs) on company stock-prices. Adjusting for market movements in general, on average stock prices rose by 1.6 percent following these strategy presentations. Strategy presentations received larger reactions the more the CEO was unfamiliar to investors. Thus stock price gains for new CEOs in general were 5.3 percent, for external, within-industry new CEOs they were 9.3 percent and for external, outside-of-industry new CEOs they were 12.4 percent. Given that only 40 percent of new CEOs present on strategy in their first 200 days post-appointment, we suggest that new CEOs pay more attention to this potential means of communicating, especially if they are unfamiliar to investors. 


\section{INTRODUCTION}

Speaking of new Chief Executives, Porter, Lorsch, and Nohria (2004: 8) propose: 'A key CEO role is to sell the strategy and shape how analysts and shareholders look at the company.' Where investors are uninformed about strategy, they face the problem of information asymmetry, a discrepancy between what investors as outsiders and managers as insiders know about prospective performance (Cohen and Dean, 2005; Zenger, 2013). Information asymmetry leads to evaluative uncertainty (Graffin and Ward, 2010), which impacts negatively on stock prices and the cost of capital (Glosten and Milgrom, 1985; Leuz and Verrecchia, 2000). This uncertainty may be particularly high in the case of new CEOs, who are typically associated with strategy change (Beatty and Zajac, 1987).

These arguments suggest there are important potential gains to informing investors about intended strategy, especially for new CEOs. However, strategic information may easily be dismissed as 'cheap talk.' Cheap talk involves promises about future actions behind which firms have not yet committed significant resources (Farrell and Rabin, 1996). Published information about strategy may be seen as 'vaporware,' designed to confuse competitors rather than be acted on (Ofek and Turut, 2013). Strategic promises appear too cheap for investors to take seriously.

This paper explores the investor impact of CEO strategy presentations, particularly those by new CEOs under varying degrees of information asymmetry. These strategy presentations (sometimes called 'strategy updates,' 'strategy reviews' and similar) involve discussions of firms' overall strategies, and thus have a broader scope than the announcements of specific strategic moves featured in previous literature (e.g. Gulati, Lavie, and Singh, 2009). Concerned with future strategy, these presentations are a form of anticipatory impression management, in other words, attempts at positively influencing audiences' perceptions of upcoming events 
(Elsbach, Sutton, and Principe, 1998). Despite doubts from a cheap talk perspective, we find that strategy presentations are effective means of impression management, particularly under conditions of greater information asymmetry, as for new CEOs of various types.

\section{THEORY AND HYPOTHESES}

Our focus is on CEO strategy presentations given directly to invited audiences of financial analysts, investors and media. These strategy presentations are public rather than internal, and concern the future of the whole business, rather than announcements of specific events such as acquisitions, R\&D projects, or joint ventures (Narayanan, Pinches, Kelm, and Lander, 2000; Gulati et al., 2009; Capron and Pistre, 2002). Reflecting trends towards greater strategy openness, about 20 percent of Global Fortune 500 corporations now make such strategy presentations in any particular year (Whittington and Yakis-Douglas, 2012; Whittington, Cailluet, and Yakis-Douglas 2011). An example from our sample illustrates. In November 2008, three months after appointment as Vodafone CEO, Vittorio Colao gave a 'strategy update' to investors and specialist media. Colao's update played down acquisitions and emphasized plans for Vodafone's existing businesses, for instance the mobile internet and telecoms services. Colao apparently persuaded investors that he had the 'speed, focus, and efficiency in implementing his new strategy... to see the company through what was the worst recession since its listing in 1988' (Financial Times, 26, November, 2008). In a falling market, Vodafone's shares rose by 6.65 percent over two days.

Vodafone's strategy presentation appears to have conveyed significant, positive information to investors. As such, it can be seen as a case of effective 'impression management' in financial markets, similar to an earnings forecast, press release or senior management 
conference call (Washburn and Bromiley, 2014). Like conference calls, such strategy presentations rely heavily on 'verbal' means of impression management, not just hard financial numbers (Westphal and Graebner, 2010). They are also forward-looking, exercises in 'anticipatory' impression management aimed at influencing perceptions of future events (Elsbach et al., 1998). Impression management may be particularly important in the uncertain conditions of a new CEO (Graffin, Carpenter, and Boivie, 2011), as in Vodafone's case.

However, CEO presentations about future strategy could be dismissed as 'cheap talk.' Such cheap talk involves low cost, non-binding and non-verifiable messages intended to affect others' beliefs about future behavior, potentially to the advantage of the talker (Farrell and Rabin, 1996; Almazan, Banerji, and Motta, 2008). Because cheap to make and hard to enforce, the public presentation of a strategic plan (for instance to invest in a market) might be suspected of aiming only to confuse or warn off competitors, rather than projecting true intentions. For the firm, the apparent advantage of such strategy presentations is how inexpensive they are as a form of deterrence, at least relative to the likely cost of fighting a competitor's entry into the market at stake (Farrell, 1987). Like phoney new software announcements, strategy presentations could be mere 'vaporware' (Ofek and Turut, 2013). If so, investors are liable to discount such talk precisely because of its cheapness. Firms have not yet put serious resources behind their claims; they can easily fail to follow through. In this view, the market is unlikely to react to strategy presentations as they are too cheap to be credible.

None the less, although strategy presentations may be cheap in financial terms, there may be reputational costs to both the firm and CEO in failing to follow through on promises (Ferreira and Rezende, 2007). Failure to meet voluntary financial predictions typically leads to a loss of confidence in financial markets (Graham, Harvey, and Rajgopal, 2005). CEOs in particular risk 
dismissal in the case of disappointed financial expectations (Wiersema and Zhang, 2011). Strategic expectations may be similar: a CEO's labor market value will fall if perceived as unable to deliver on strategy (Ferreira and Rezende, 2007). Given such potential reputational costs, there may be reason for investors to take strategy presentations seriously.

There is mixed empirical evidence on the significance of CEO 'talk' in general. Brooks, Johnson, and Su (1997) find that CEO presentations to analysts, which often include strategy discussions alongside a range of other kinds of information, have negligible impacts on a range of market measures. The inclusion of 'soft' verbal information, equivalent to that in strategy presentations, appears to add nothing to the 'hard' quantitative information of earnings forecasts (Hutton, Miller, and Skinner, 2003). More positively, Bagnoli, Levine, and Watts (2005a; 2005b) show significant market reactions to a range of 'strategic' information (from strategy presentations to joint venture or acquisition announcements), though lower than to those for quantitative earnings guidance. Westphal and Graebner (2010) find that CEO verbal impression management with regard to governance arrangements can elevate analysts' evaluations. Verbal impression management in the form of senior management conference calls with analysts appears to impact particularly where present earnings are significantly below or above target (Washburn and Bromiley, 2014).

Our study focuses on the broader plans involved in strategy presentations, rather than specific announcements such as R\&D projects, joint ventures or acquisitions (Narayanan et al., 2000; Gulati et al., 2009; Capron and Pistre, 2002) that typically involve immediate commitments. Presentations of broad plans for the future are generally less committal and therefore more liable to doubt. However, contrary to the scepticism of cheap talk theorists (e.g. Farrell, 1987), we propose that these strategy presentations can be an effective form of 
impression management: at the least, reputational costs exert a discipline on CEOs (Ferreira and Rezende, 2007). We therefore examine whether strategy presentations are indeed events whose information content can impress investors sufficiently to influence the market price of company stock. Our baseline hypothesis is:

Hypothesis 1: Strategy presentations will have a significant impact on stock prices, either positively or negatively

Our following hypotheses move from this baseline to consider conditions of increasing information asymmetry, starting with presentations by new CEOs in general and then examining specific new CEO characteristics liable to be associated with greater investor uncertainty.

\section{Strategy presentations in the context of a new CEO}

New CEOs are associated with strategic change (Beatty and Zajac, 1987; Weng and Lin, 2012). The new CEO's first strategy presentation typically comes at a time of heightened investor uncertainty therefore. Given the CEO's critical responsibility for strategy (Montgomery, 2008), analysts and investors are keen to assess their experience and competence (Tian, Haleblian, and Rajagopalan, 2011). Moreover, through management team changes, a new CEO can more generally alter the knowledge and skills at the top of the company, again with implications for strategy (Virany, Tushman, and Romanelli, 1992; Zhang and Rajagopalan, 2004). Our second hypothesis therefore examines whether the heightened uncertainty associated with new CEOs is reflected in greater investor sensitivity to their strategy presentations:

\section{Hypothesis 2: Strategy presentations by new CEOs will elicit a greater stock price} reaction than strategy presentations that are carried out by established chief executives.

Various characteristics of a new CEO can also affect investor confidence (Tian et al., 2011). Incoming CEOs vary in terms of 'newness', for example according to their familiarity to investors, or their experience with the specific firm or specific industry (Weng and Lin, 2012). In general, if a CEO is new to investors, firm or industry, this creates greater uncertainty about 
future strategy. We focus therefore on the following three types of new CEO likely to be associated with increased investor sensitivity to strategy presentations.

Internal, non-heir apparent new CEOs. Our first type is CEOs that are appointed from inside the firm but are not heir apparents. An heir apparent CEO will have taken part in setting the existing strategic direction, and therefore investors will expect less change in strategy (Zhang and Rajagopalan, 2010). Also, an heir apparent CEO will likely have been introduced to investors as part of the grooming process before appointment (Zhang and Rajagopolan, 2004), so that their strategy predilections may be known already. Hence, relative to an insider heir apparent CEO, a strategy presentation by an insider non-heir apparent CEO is likely to meet with greater investor reactions, because of uncertainty and expectations of change.

Because boards typically recruit externally when dissatisfied with existing performance, new CEOs from outside the firm are particularly associated with strategic change (Clayton, Hartzell, and Rosenberg, 2005; Weng and Lin, 2012). We distinguish two types of external new CEO according to industry experience.

External, within-industry new CEOs. These are from outside the firm but from within its industry. Coming from the same industry, they are likely to be imbued with the common strategic 'recipe' of that industry (Spender, 1996), so investors will expect change to be within familiar parameters. None the less, as externals, they will still carry high expectations of strategic change (Clayton et al, 2005).

External, outside-of-industry new CEOs. External CEOs from outside the firm's home industry will be governed more by the distinctive recipe of their own original industry (Spender, 1996) and are therefore likely to introduce more significant change than industry insiders. Analysts, who tend to specialize by industry (Zuckerman, 2000), will have little information about the new 
CEO's recipe. Presentations by external, outside-of-industry new CEOs are therefore likely to evoke greater investor reactions than those that are carried out by established chief executives..

These arguments regarding various CEO characteristics associated with heightened information asymmetry lead to the following three sub-hypotheses:

Hypothesis 3(a-c): Strategy presentations by a) internal, non-heir apparent new CEOs; b) external, within-industry new CEOs; c) external, outside-of-industry new CEOs will elicit greater stock price reactions than those carried out by established chief executives.

\section{METHODS}

\section{Sample, data collection, and sources}

Our dataset comprises of companies on the NYSE or NASDAQ exchange that carried out strategy presentations in the period from 1 January 2000 to 30 December 2010 . We electronically searched Thomson Reuters StreetEvents for these presentations under the search terms 'strategy presentation,' 'strategy meeting,' 'strategy announcement,' 'strategy review,' and 'strategy update.' We included in our dataset only presentations that were public and relevant to the whole business (rather than specific events such as acquisitions).

The screening process was as follows. To start with, the first and second authors independently browsed through potentially relevant events on StreetEvents. They then reviewed a randomly-selected 30 events together, debating which events were relevant and drafting a protocol (available from authors on request) for inclusion/exclusion criteria. Using this protocol, one author identified an initial pool of 3750 potentially relevant events using the key search terms (strategy presentation etc.). The first and second authors next randomly sampled 220 events from this initial pool of data and reviewed them independently for inclusion/exclusion decisions. Their independent assessment resulted in twelve disagreements (95\% agreement). They reconciled differences by talking to each other and made appropriate changes to the 
protocol. The dataset was then modified according to the new protocol. Next, the two authors randomly selected a further 200 events from the modified dataset and reviewed them in terms of inclusion/exclusion decisions. This time, their agreement rate was 94 percent. Once again, they reconciled differences through talking to each other, making appropriate changes to the protocol and the dataset. The two authors then randomly selected 54 additional events for review and this time their agreement rate was 98 percent (the disagreement was resolved by discussion). As a final check, an independent coder reviewed 375 of the previously reviewed events $(10 \%$ of the initial events). Using Krippendorff's alpha, the intercoder reliability quotient for the three coders was 0.95, where 1.00 signifies perfect agreement (Hayes and Krippendorff, 2007). In the light of this review, we revised the whole dataset to add three more observations making a total of 1649.

Because we use an event study methodology, we follow McWilliams and Siegel (1997) by also screening out confounding events such as declarations of dividends, mergers and acquisitions, earnings announcements, major contract awards, new product announcements, and significant liability suits during a 21-day window (from day -10 to day +10 ) around the strategic plan presentations. Our source for these events was Factiva and Lexis/Nexis. 773 strategy presentations were excluded as a result, leaving a final dataset of 876 presentations $(23 \%$ of the initial pool).

We focus our main analysis on CEOs appointed 100 days or less prior to the strategy presentation, held to be a crucial period for new CEOs (Gabarro, 1987; Neff and Citrin, 2005). However, we shall also allow for a more extended definition of early-stage CEOs by considering presentations given in the first 200 days of appointment, the second half of which is often seen as a period in which initial changes gain crucial momentum (Murray and Richardson, 2003). We 
thus considerably extend the range of earlier research on impression management by new CEOs, which has focused on the three days surrounding initial announcement (Graffin et al., 2011).

\section{Measures}

The objective of our study is to analyse stock price responses to strategy presentations through employing event study methodology (Brown and Warner, 1985; McWilliams and Siegel, 1997). Event studies are very common within both the strategic management (Narayanan et al., 2000; Gulati et al., 2009; Capron and Pistre, 2002) and voluntary disclosure literatures (Healy and Palepu, 2001). In this study, we treat stock price responses as measures of how strategy presentations impress investors in the short-term; we do not interpret stock price responses as necessarily effective measures of eventual economic returns (Oler, Harrison, and Allen, 2008).

\section{Dependent variable: Cumulative abnormal returns}

We calculate CAR using a market model for each firm with an estimation window and calculate the deviation using expected returns and actual returns for every firm (source: Datastream). We use a NYSE and NASDAQ equally weighted index that indicates price trend movements based on a broad cross-section of the market. To estimate the market model, we use the 260 trading day prior to the event window as the estimation window (MacKinlay, 1997). The length of the period in our study is consistent with prior studies in the management literature (McWilliams and Siegel, 1997). To calculate CAR, our main analysis uses a short event window of 3 days ( $\mathrm{t}=-1$ to +1 ), measuring immediate investor impressions. Long windows may include confounding effects that lead to false inferences about the significance of an event (McWilliams and Siegel, 1997). The -1 day allows for leakage of information prior to the presentation itself (Schijven and Hitt, 2012). For our model estimation, we used a static linear panel data model where CARit is the cumulative abnormal return for firm $i$ for event $t$. 


\section{Independent variables}

Strategy presentations. We treat strategy presentations as events liable to generate cumulative abnormal returns (CAR) in the financial market (McWilliams and Siegel, 1997). We collected data regarding strategy presentations using StreetEvents.

New CEOs' strategy presentations. We define a new CEO as someone who has been appointed to the role of Chief Executive in a given organization up to 200 days prior to carrying out his or her first strategy presentation. We coded new chief executive as a binary variable: ' 1 ' for those appointed in the 100 (or 200) days prior to strategy presentations and ' 0 ' otherwise. Similar to previous studies (Tian et al., 2011; Lee and James, 2007), we gathered data on new chief executives by searching OneSource for the CEO's appointment date, Factiva and Lexis/Nexis for succession announcements and company websites where necessary.

\section{Moderating variables}

We construct our moderating variables using newly appointed CEOs' characteristics associated with heightened information asymmetry.

Internal, non-heir apparent new CEOs' strategy presentations. We coded ' 1 ' if the new CEO presenting his/her strategy was appointed from inside the organization but was not an heir apparent, and ' 0 ' if otherwise. Heir-apparents were those who had previously held the title of president, chief operating officer $(\mathrm{COO})$ or both in the firm and who were at least five years younger than the incumbent CEO (Cannella and Shen, 2001).

External, within-industry new CEOs' strategy presentations. We coded ' 1 ' if the new CEO presenting his/her strategy was appointed from outside the organization (but from inside their main industry) and '0’ otherwise (Zhang and Rajagopalan, 2004). 
External, outside-of-industry new CEOs' strategy presentations. We coded ' 1 ' if the new CEO presenting his/her strategy was appointed from outside the firm's main industry (and organization) and ' 0 ' otherwise, using the two-digit Standard Industrial Classification (SIC) code (Tian et al., 2011).

\section{Control variables}

Following literature on voluntary disclosures and new CEOs, we chose control variables relevant to possible effects on information, as follows: (1) firm size (Mazzola, Gnan, and Lisi, 2007; Griffin, 2003), (2) low analyst following (Bagnoli et al., 2005a), (3) stock price volatility (Kothari, Loutskina, and Nikolaev, 2006), (4) financial distress, based on an industry adjusted Zscore (Kothari, Shu, and Wysocki, 2009), (5) managerial ownership (Eng and Mak, 2003; Hutton, 2005), (6) litigation (Healy and Palepu, 2001), (7) contest for corporate control (Healy and Palepu, 2001), (8) newness to a particular financial market (Webb, Cahan, and Sun, 2008), (9) large calls on shareholders (Healy and Palepu,1995), (10) regular presentations, (11) industry instability (Finkelstein and Hambrick, 1996; Zhang and Rajagopalan, 2004), (12) strategic instability (Hambrick and Finkelstein, 1987; Zhang and Rajagopalan, 2004), (13) non-U.S. firms, (14), business complexity (Zuckerman, 2000), (15) firm age (Sanders and Boivie, 2004), (16) CEO age (Zhang and Rajagopalan, 2010; Graffin et al., 2011), and (17) year dummies.

\section{RESULTS \\ Our purpose is twofold: first to address the baseline hypothesis on whether strategy presentations have any impact on investors as measured by stock price; second, to test whether investors are more sensitive to strategy presentations associated with varying degrees of information asymmetry due to the characteristics of the presenting CEO.}




\section{Strategic Management Journal}

\section{Insert Table 1, Table $2 \&$ Table 3}

Table 1 provides the number of observations relating to new CEO strategy presentations and Table 2 presents descriptive statistics and correlations. Out of the total of 966 new CEO appointments in our ten year study period, 23.8 percent made presentations in the first 100 days of their tenure, and 39.7 percent presented in their first 200 days. For those in the first 100 days, presentations were made on average 28 days after appointment (the fastest was 16 days). Despite a relatively strong correlation between financial distress and share price volatility (correlation coefficient: $0.32, \mathrm{p}<0.05$ ), we found that variance inflation factors (VIF) values ranged between 1.12 and 2.09 for variables in our regression models, lower than the commonly accepted threshold values for multicollinearity (Hair, Anderson, Tatham, and Black, 1998).

Table 3 provides our stepwise regression analysis. Following Carpenter (2002), we exclude non-significant control variables from our tables but not our results. CAR associated with strategy presentations on day zero is 1.6 percent $(\mathrm{p}<0.05)$ (see Model $1 b)$. At the mean, this represents a positive change of $\$ 162$ million in market capitalization. We conclude in favour of our baseline hypothesis 1 that strategy presentations do impact stock prices. Strategy presentations are potentially an effective form of impression management, not just 'cheap talk.'

We turn now to the conditions of greater information asymmetry. We test firstly for presentations carried out in the first 100 days of CEO tenure. Model 2 considers the impact of our independent variable and models 3-5 test effects of our moderating variables. We find that each of these variables is associated with significant CAR. The subsequent models (6 and 7a) introduce successively the combined effects of all our variables. Out of sixteen control variables (including year dummies), nine are significant (significance levels vary between $\mathrm{p}<0.10$ and 
$\mathrm{p}<0.01$ ). Model 7a drops non-significant control variables (i.e. size, litigation, contest for corporate control, new to a particular financial market, non-US, firm age, and new CEO age).

We start with hypothesis 2 , which states that newly appointed CEOs' strategy presentations will be associated with greater stock price reactions compared to those carried out by established chief executives. Model 7a in Table 3 indicates that new CEO strategy presentations are weakly associated with positive average cumulative abnormal returns (regression coefficient: 0.05; $\mathrm{p}<0.1)$. Hypothesis 2 receives some support.

We turn now to specific CEO characteristics associated with greater information asymmetry regarding strategy. We find weak support for hypothesis $3 a$ (coefficient: $0.06 ; p<0.1$ ), which tests CAR associated with strategy presentations given by internal, non-heir apparent new CEOs. We find stronger support for hypotheses $3 b$ and $3 c$, which test for CAR associated with presentations given by external, within-industry new CEOs or external, outside-of-industry new CEOs (regression coefficients for respective variables are 0.09 and $0.12 ; \mathrm{p}<0.01$ for both). External appointments appear particularly important for investor reactions.

Given the longer early-stage period proposed by Murray and Richardson (2003), we also tested for whether our regression results for the first 100 days of the new CEO's appointment also hold for the first 200 days. Model $7 \mathrm{~b}$ in Table 3 includes the results of a regression analysis for the first 200 days of a CEO's appointment, using the same variables as in Model 7a. The regression results on the first 200 days are broadly in line with those for the first 100 days. None the less we observe that in the longer period the magnitudes of coefficients for our main effects variables are comparably lower than those for the shorter period (coefficients of our variables in Model 7a vary between $0.05(p<0.1)$ and $0.12(p<0.01)$ whereas the relevant coefficients in 
Model $7 \mathrm{~b}$ vary between 0.02 (not significant) and $0.10(\mathrm{p}<0.01)$, as well as being accompanied by weaker p-values, adjusted R-squares and RMSE figures.

Cohen's d (the standardized mean difference) for our hypotheses variables in models $7 \mathrm{a}$ and $7 \mathrm{~b}$ vary between 1.09 and 0.43 indicating strong or moderate effects (Cohen, 1988). On average, strategy presentations in the first 100 days produce a positive move in the stock market of approximately $\$ 996$ million (12.4\%) for external, outside-of-industry new CEOs, $\$ 713$ million (9.3\%) for external, within-industry new CEOs, \$519 million (6.1\%) for internal, non-heir apparent new CEOs and \$450 million (5.3\%) for new CEOs in general.

For robustness checks, we conducted additional analyses using CARs based on five ($2,+2)$, twenty-three $(-11,+11)$ and forty-three $(-21,+21)$ trading days surrounding the strategy presentation. Taking longer and multiple windows allow for earlier leakage of information and delayed investor reactions (Schijven and Hitt, 2012). With the exception of new CEOs in general, and internal, non-heir apparent new CEOs within the forty-three day window, variables that are significant for three day windows $(-1,+1)$ are broadly significant for the longer windows as well (significance levels vary between $\mathrm{p}<0.1$ and $\mathrm{p}<0.01$ for main effects variables within a five-day window; $\mathrm{p}<0.1$ and $\mathrm{p}<0.05$ within a twenty-three day window; and two main effects variables were significant with $\mathrm{p}<0.05$ each within a forty-three day window). The explanatory power of the overall model and the magnitudes of regression coefficients for the main effects variables are highest for our original and shortest window (i.e. $-1,+1$ days).

We address possible endogeneity issues as follows. Companies choosing to present do not significantly differ from non-presenting ones in terms of market capitalization or ROA Although the average yearly market capitalization and ROA of presenting firms are $2.8 \%$ and $3.4 \%$ higher respectively than the yearly averages of non-presenting firms within corresponding 
industries, T-tests show that these differences are insignificant (at the 0.05 level). The distribution of investor reactions to strategy presentations suggests little selection bias according to expected reactions: $40.9 \%$ received no statistically significant reaction $(p<0.05), 32.8 \%$ received significant positive reactions, $26.3 \%$ received significant negative reactions. A medians test, which does not require that distributions be symmetric or normally distributed, suggests that there are no significant differences between categories of positive and negative investor reactions to strategy presentations at $\mathrm{p}<0.05$ level. We ran the same regressions for just those presentations that received positive reactions and obtained similar results, though at lower levels of significance. Our controls also address a wide range of factors associated with propensity to undertake voluntary disclosures (Healy and Palepu, 2001). As investors and analysts typically follow firms for some time, and we exclude presentations with confounding events such as earnings announcements and financial transactions, the strategy presentation is likely to be the main new information during our three day event window.

\section{DISCUSSION}

Information asymmetry between investors and management regarding strategy is liable to be costly for firms. 'Selling' strategy to analysts and shareholders is therefore a key role for CEOs (Porter et al., 2004; Zenger, 2013). We demonstrate the importance of a previously-neglected form of selling strategy, CEO strategy presentations. Despite their verbal, forward-looking nature, these are not necessarily 'cheap talk' (Farrell and Rabin, 1996). Rather we find that strategy presentations can be an effective form of anticipatory impression management by CEOs, especially in the uncertain months following their initial appointment (Elsbach et al., 1998). We thus add strategy presentations to the repertoire of effective impression management tools in 
financial markets (Washburn and Bromiley, 2014), consistent with interest in more open strategy (Whittington et al, 2011). We also extend our knowledge about the importance of impression management beyond the few days immediately surrounding CEO appointment (Graffin et al., 2011).

In particular, consistent with hypothesis 1, we find that strategy presentations in general have a significant positive impact on stock prices, our measure of impression management. In this sense, contrary to scepticism from theorists of cheap talk, investors see strategy presentations as credible and economically significant. Strategy talk matters. Investors particularly value strategy presentations in the conditions of heightened information asymmetry associated with external, within-industry new CEOs or external, outside-of-industry new CEOs (hypotheses $3 \mathrm{~b}$ and $3 \mathrm{c}$ ): positive stock market moves are $9.3 \%$ and $12.4 \%$ respectively. There is weaker support for investors responding more to strategy presentations by new CEOs in general and by internal, non-heir apparent new CEOs (hypotheses 2 and 3a).

We draw attention to two limitations of this study, each offering opportunities for further research. First, while we suggest that strategy presentations can be received positively by investors, we do not look inside presentations to analyse their specific content. For example, the content of strategy presentations could now be analysed for the extent to which they make use of authoritative language regarding strategy and leadership (Rindova, Becerra and Contardo, 2004; Fanelli, Misangyi and Tosi, 2009). Second, we have not addressed directly why some firms carry out strategy presentations and some do not. The majority of NYSE and NASDAQ firms do not present regularly, by contrast with their practice regarding earnings guidance, for example. Further research on antecedents to this form of impression management is warranted, equivalent to that by Westphal and Graebner (2010) with regard to governance. 
Our findings may have practical implications for whether and when to use strategy presentations. First, strategy presentations appear surprisingly little-used. In our sample, substantially less than half of new CEOs carried out strategy presentations in their first 200 days and less than a quarter did so in their first 100 days. These proportions are even lower for external and inexperienced new CEOs. Yet strategy presentations overall are positively received and new CEOs generate better responses from their presentations if they have external status. Second, timing can make a difference for new CEOs. Effects are greater within the first 100 days than the first 200. New CEOs and especially those that have external status should contemplate the upside potential of strategy presentations and the diminishing returns from delay.

\section{REFERENCES}

Almazan A, Banerji S, Motta AD. 2008. Attracting attention: Cheap managerial talk and costly market monitoring. Journal of Finance 63(3): 1399-1436.

Bagnoli M, Levine S, Watts S. 2005a. Analyst estimation revision clusters and corporate events. Part I, Annals of Finance 1(3): 245-265.

Bagnoli M, Levine S, Watts S. 2005b. Analyst estimation revision clusters and corporate events. Part II, Annals of Finance 1(4): 379-393.

Beatty RP, Zajac EJ. 1987. CEO change and firm performance in large corporations: Succession effects and manager effects. Strategic Management Journal 8(4): 305-317.

Brooks R, Johnson M, Su T. 1997. CEO presentations to financial analysts: Much ado about nothing?. Financial Practice and Education 7(2): 19-23.

Brown S, Warner J. 1985. Measuring security price performance. Journal of Financial Economics 8(3): 205-258.

Cannella AA, Shen W. 2001. So close and yet so far: Promotion versus exit for CEO heirs apparent. Academy of Management Journal 44(2): 252-270.

Capron L, Pistre N. 2002. When do acquirers earn abnormal returns?. Strategic Management Journal 23(9): 781-794.

Carpenter MA. 2002. The implications of strategy and social context for the relationship between top management team heterogeneity and firm performance. Strategic Management Journal, 23(3): 275 284.

Clayton MC, Hartzell JC, Rosenberg J. 2005. The Impact of CEO Turnover on Equity Volatility. The Journal of Business 78(5): 1779-1808.

Cohen J. 1988. Statistical Power for the Behavioral Sciences (2nd ed). Lawrence Erlbaum: Hillsdale, NJ.

Cohen BD, Dean TJ. 2005. Information asymmetry and investor valuation of IPOs: Top management team legitimacy as a capital market signal. Strategic Management Journal, 26(7): 683-690.

Elsbach KD, Sutton RI, Principe KE. 1998. Averting expected challenges through anticipatory impression management: a study of hospital billing. Organization Science 9(1): 68-86.

Eng LL, Mak YT. 2003. Corporate governance and voluntary disclosure. Journal of Accounting and Public Policy 22(4): 325-345. 
Fanelli A, Misangyi VF, Tosi H L. 2009. In charisma we trust: The effects of CEO charismatic visions on securities analysts. Organization Science 20(6): 1011-1033.

Farrell J, Rabin M. 1996. Cheap talk. Journal of Economic Perspectives 10(3): 103-118.

Farrell J. 1987. Cheap Talk, Coordination, Entry. RAND Journal of Economics 18(1): 34-39.

Ferreira D, Rezende M. 2007. Corporate strategy and information disclosure. The RAND Journal of Economics 38(1): 164-184.

Finkelstein S, Hambrick DC. 1996. Strategic leadership: Top executives and their effects on organizations. Minneapolis/St. Paul: West Educational Publishing.

Gabarro JJ. 1987. The dynamics of taking charge. Boston: Harvard Business School Press.

Glosten L, Milgrom P. 1985. Bid, ask, and transaction prices in a specialist market with heterogeneously informed traders. Journal of Financial Economics 13(1): 71-100.

Graffin SD, Carpenter MA, Boivie S. 2011. What's all that (strategic) noise? Anticipatory impression management in CEO succession. Strategic Management Journal 32(7): 748-770.

Graffin SD, Ward AJ. 2010. Certifications and reputation: Determining the standard of desirability amidst uncertainty. Organization Science 21(2): 331-346.

Graham JR, Harvey CR, Rajgopal S. 2005. The economic implications of corporate financial reporting. Journal of accounting and economics 40(1): 3-73.

Griffin P. 2003. Got Information? Investor Response to Form 10-K and Form 10-Q EDGAR Filings. Review of Accounting Studies 8(4): 433-460.

Gulati R, Lavie D, Singh H. 2009. The nature of partnering experience and the gains from alliances. Strategic Management Journal 30(11): 1213-1233.

Hair JF, Anderson RE, Tatham RL, Black WC. 1998. Multivariate Data Analysis with Readings 5th Edition. Englewood Cliffs, NJ, Prentice Hall.

Hambrick DC, Finkelstein S. 1987. Managerial discretion: A bridge between polar views of organizational outcomes. Research in Organizational Behavior 9: 369-406.

Hayes AF, Krippendorff K. 2007. Answering the call for a standard reliability measure for coding data. Communication Methods and Measures 1: 77-89.

Healy P, Palepu K. 1995. The Challenges of investor communication: the case of CUC International. Journal of Financial Economics 38(2): 111-140.

Healy P, Palepu K. 2001. Information asymmetry, corporate disclosure, and the capital markets: A review of the empirical disclosure literature. Journal of accounting and economics 31(1): 405-440.

Hutton A, Miller G, Skinner D. 2003. The Role of Supplementary Statements with Management Earnings Forecasts. Journal of Accounting Research 41(5): 867-890.

Hutton A. 2005. Determinants of Managerial Earnings Guidance Prior to Regulation Fair Disclosure and Bias in Analysts' Earnings Forecasts. Contemporary Accounting Research 22(4): 867-914.

Kothari SP, Loutskina E, Nikolaev V. 2006. Agency Theory of Overvalued Equity as an Explanation for the Accrual Anomaly. Unpublished paper, MIT Sloan School of Management.

Kothari SP, Shu S, Wysocki PD. 2009. Do managers withhold bad news?. Journal of Accounting Research 47(1): 241-276.

Lee PM, James EH. 2007. 'She'-e-os: gender effects and investor reactions to the announcements of top executive appointments. Strategic Management Journal 28(3): 227-241.

Leuz C, Verrecchia R. 2000. The economic consequences of increased disclosure. Journal of Accounting Research 38: 91-124.

MacKinlay A. 1997. Event studies in economics and finance. Journal of Economic Literature 35(1): 1339.

Mazzola P, Gnan L, Lisi I. 2007. The information content of strategy presentations of Italian listed companies. Unpublished working paper, IULM University, Milan.

McWilliams A, Siegel D. 1997. Event studies in management research: Theoretical and empirical issues. Academy of Management Journal 40(3): 626-657.

Montgomery CA. 2008. Putting leadership back into strategy. Harvard Business Review 86(1): 54-60. 


\section{Strategic Management Journal}

Murray EJ, Richardson PR. 2003. Fast forward: a new framework for rapid organizational change. Ivey Business Journal 67(6): 1-5.

Narayanan VK, Pinches GE, Kelm KM, Lander DM. 2000. The influence of voluntarily disclosed qualitative information. Strategic Management Journal 21(9): 707-722.

Neff TJ, Citrin JM. 2005. You're in charge: Now what? New York: Crown Business.

Ofek E, Turut Ö. 2013. Vaporware, suddenware, and trueware: new product preannouncements under market uncertainty. Marketing Science 32(2): 342-355.

Oler DK, Harrison JS, Allen MR. 2008. The danger of misinterpreting short-window event study findings in strategic management research: an empirical illustration using horizontal acquisitions. Strategic Organization 6(2): 151-184.

Porter ME, Lorsch JW, Nohria N. 2004. Seven surprises for new CEOs. Harvard Business Review 82(10): $62-75$.

Rindova VP, Becerra M, Contardo I. 2004. Enacting competitive wars: Competitive activity, language games, and market consequences. Academy of Management Review 29(4): 670-686.

Sanders G, Boivie S. 2004. Sorting things out: Valuation of new firms in uncertain markets. Strategic Management Journal 25(2): 167-186.

Schijven M, Hitt MA. 2012. The vicarious wisdom of crowds: toward a behavioral perspective on investor reactions to acquisition announcements. Strategic Management Journal 33(11): 1247-1268.

Shen W, Cannella AA. 2003. Will succession planning increase shareholder wealth? Evidence from investor reactions to relay CEO successions. Strategic Management Journal 24(2): 191-198.

Spender JC. 1996. Making knowledge the basis of a dynamic theory of the firm. Strategic Management Journal 17(S2): 45-62.

Tian J, Haleblian J, Rajagopalan N. 2011. The effects of board human and social capital on investor reactions to new CEO selection. Strategic Management Journal 32(7): 731-747.

Virany B, Tushman ML, Romanelli E. 1992. Executive succession and organizational outcomes in turbulent environments: An organizational learning approach. Organization Science 3(1): 72-91.

Washburn M, Bromiley P. 2013. Managers and analysts: An examination of mutual influence. Academy of Management Journal 57 (3): 849-69.

Webb K, Cahan S, Sun J. 2008. The effect of globalization and legal environment on voluntary disclosure. International Journal of Accounting 43(3): 219-245.

Weng DH, Lin ZJ. 2012. Beyond CEO tenure: The effect of CEO newness on strategic changes. Journal of Management 40 (7): 2009-2032

Westphal JD, Graebner ME. 2010. A matter of appearances: How corporate leaders manage the impressions of financial analysts about the conduct of their boards. Academy of Management Journal 53(1): $15-44$.

Whittington, R. and Yakis-Douglas, B. 2012. Strategic Disclosure Strategy as a Form of Reputation Management. In Pollock, T., Barnett, M. (eds). Handbook of Corporate Reputation. Oxford University Press.

Whittington, R., Cauilliet, L. and Yakis-Douglas, B. 2011. Opening Strategy: Evolution of a Precarious Profession. British Journal of Management, 22(3): 341-564.

Wiersema MF, Zhang Y. 2011. CEO dismissal: the role of investment analysts. Strategic Management Journal 32(11): 1161-1182.

Zenger T. 2013. Strategy: The uniqueness challenge. Harvard Business Review 91(11): 52-59.

Zhang Y, Rajagopalan N. 2004. When the known devil is better than an unknown god: an empirical study of the antecedents and consequences of relay CEO successions. Academy of Management Journal 47(4): 483-500.

Zhang Y, Rajagopalan N. 2010. Once an outsider, always an outsider? CEO origin, strategic change, and firm performance. Strategic Management Journal 31(3): 334-346.

Zuckerman EW. 2000. Focusing the corporate product: Securities analysts and de-diversification. Administrative Science Quarterly 45(3): 591-619. 
Table 1: Number of observations relating to new CEOs

\begin{tabular}{|c|c|c|c|}
\hline & \multicolumn{2}{|c|}{ Strategy presentations } & \multirow{2}{*}{$\begin{array}{c}\text { Total number of appointments } \\
10 \text { years }\end{array}$} \\
\hline Variables & 100 days & 200 days & \\
\hline New CEOs' strategy presentations & 230 & 384 & 966 \\
\hline Internal, non-heir apparent new CEOs' strategy presentations & 44 & 81 & 142 \\
\hline External, outside-of-industry new CEOs' strategy presentations & 21 & 34 & 124 \\
\hline
\end{tabular}

Table 2: Descriptive statistics and Correlations

\begin{tabular}{|c|c|c|c|c|c|c|c|c|c|c|c|c|c|c|c|c|c|c|c|c|c|c|c|c|c|}
\hline $\begin{array}{l}17 \\
18\end{array}$ & $\begin{array}{c}\text { Variables (876 strategy } \\
\text { presentations) }\end{array}$ & Mean & $\begin{array}{c}\text { St. } \\
\text { Dev. }\end{array}$ & 1 & 2 & 3 & 4 & 5 & 6 & 7 & 8 & 9 & 10 & 11 & 12 & 13 & 14 & 15 & 16 & 17 & 18 & 19 & 20 & 21 & 22 \\
\hline 191 & $\begin{array}{l}\text { Strategy presentations } \\
\text { (SP) }\end{array}$ & 0.61 & 0.23 & 1 & & & & & & & & & & & & & & & & & & & & & \\
\hline 20 & New CEOs' SP & 0.24 & 0.11 & $0.17 \dagger$ & 1 & & & & & & & & & & & & & & & & & & & & \\
\hline $\begin{array}{l}21 \\
22^{3}\end{array}$ & $\begin{array}{l}\text { Internal, non-heir } \\
\text { apparent new CEOs' SP }\end{array}$ & 0.31 & 0.08 & 0.04 & 0.12 & 1 & & & & & & & & & & & & & & & & & & & \\
\hline $23^{4}$ & $\begin{array}{l}\text { External, within- } \\
\text { industry new CEOs' SP }\end{array}$ & 0.09 & 0.03 & 0.06 & 0.08 & $0.21 \dagger$ & 1 & & & & & & & & & & & & & & & & & & \\
\hline $\begin{array}{l}245 \\
25\end{array}$ & $\begin{array}{l}\text { External, outside-of- } \\
\text { industry new CEOs' SP }\end{array}$ & 0.17 & 0.05 & $0.11 \dagger$ & $0.13 \dagger$ & $0.20^{*}$ & $0.25^{*}$ & 1 & & & & & & & & & & & & & & & & & \\
\hline 6 & Size & 1.E-10 & $4.76 \mathrm{E}-10$ & -0.08 & 0.00 & -0.03 & -0.16 & -0.04 & 1 & & & & & & & & & & & & & & & & \\
\hline 267 & Low analyst following & 0.07 & 0.32 & -0.11 & 0.04 & -0.01 & -0.07 & -0.09 & $0.22 \dagger$ & 1 & & & & & & & & & & & & & & & \\
\hline $27^{8}$ & Share price volatility & 41.52 & 12.09 & -0.09 & 0.10 & -0.00 & $0.13 \dagger$ & $0.16^{*}$ & 0.14 & -0.11 & 1 & & & & & & & & & & & & & & \\
\hline $28^{9}$ & Financial distress & 32.54 & 14.21 & 0.13 & $0.17 \dagger$ & 0.08 & 0.10 & $0.19^{*}$ & 0.13 & -0.05 & $0.32^{*}$ & 1 & & & & & & & & & & & & & \\
\hline 2810 & Former CEO & 0.02 & 0.02 & 0.07 & 0.10 & 0.06 & $0.18 \dagger$ & $0.20^{*}$ & -0.08 & 0.06 & -0.01 & -0.04 & 1 & & & & & & & & & & & & \\
\hline 2911 & Managerial ownership & 0.41 & 0.15 & 0.03 & 0.06 & -0.03 & 0.04 & 0.05 & -0.09 & 0.13 & 0.16 & 0.03 & -0.02 & 1 & & & & & & & & & & & \\
\hline 12 & Litigation & 0.00 & 0.00 & 0.02 & 0.01 & 0.09 & 0.09 & 0.14 & -0.11 & 0.00 & 0.08 & 0.12 & -0.03 & 0.10 & 1 & & & & & & & & & & \\
\hline $3 U_{13}$ & Contest for corporate & 0.20 & 0.01 & -0.00 & -0.03 & -0.07 & -0.05 & -0.10 & 0.05 & -0.20 & $0.29 *$ & $0.37^{*}$ & -0.07 & 0.17 & 0.11 & 1 & & & & & & & & & \\
\hline 3114 & New to a particular & 0.35 & 0.36 & $-0.15 \dagger$ & -0.12 & 0.01 & $0.13 \dagger$ & $0.22 \uparrow$ & -0.08 & -0.19 & $0.25 \dagger$ & -0.14 & 0.21 & 0.03 & -0.19 & 0.18 & 1 & & & & & & & & \\
\hline 15 & Large calls to shareholders & 0.64 & 0.43 & 0.01 & 0.12 & 0.06 & -0.05 & -0.03 & -0.06 & -0.18 & $0.24 * *$ & $0.27^{*}$ & -0.01 & 0.12 & $0.33^{* *}$ & $0.20^{*}$ & 0.16 & 1 & & & & & & & \\
\hline $3<16$ & Regular presentations & 0.29 & 0.39 & 0.13 & $-0.25^{*}$ & 0.04 & 0.01 & 0.03 & -0.11 & -0.21 ** & -0.07 & -0.08 & 0.11 & $-0.13 \dagger$ & -0.05 & 0.19 & 0.03 & 0.11 & 1 & & & & & & \\
\hline 3317 & Industry instability & 3.27 & 1.03 & 0.10 & $0.15^{*}$ & 0.10 & $0.19 \dagger$ & $0.21^{*}$ & 0.05 & -0.06 & 0.13 & 0.09 & -0.02 & 0.07 & 0.14 & $0.19 \dagger$ & -0.08 & 0.15 & -0.06 & 1 & & & & & \\
\hline $34^{18}$ & Strategic instability & 0.46 & 0.11 & 0.09 & 0.10 & 0.14 & $0.23^{*}$ & $0.19 \dagger$ & 0.16 & -0.03 & 0.08 & 0.05 & 0.08 & 0.09 & 0.15 & $0.29 * *$ & 0.14 & 0.10 & $-0.22 * *$ & 0.06 & 1 & & & & \\
\hline 3419 & Non-U.S. & 0.16 & 0.15 & -0.03 & -0.05 & -0.10 & $0.19 \dagger$ & -0.13 & -0.05 & -0.09 & -0.06 & -0.05 & 0.16 & -0.03 & 0.10 & -0.07 & 0.01 & -0.04 & 0.10 & -0.06 & -0.08 & 1 & & & \\
\hline 3520 & Business complexity & 0.34 & 0.14 & 0.12 & 0.07 & 0.08 & $0.14 \dagger$ & -0.02 & -0.03 & -0.15 & 0.07 & -0.09 & -0.12 & $0.17 \dagger$ & -0.10 & 0.04 & 0.09 & -0.13 & -0.03 & -0.07 & 0.06 & $-0.15 \dagger$ & 1 & & \\
\hline $36^{21}$ & Firm age & 19.24 & 8.61 & 0.10 & 0.09 & 0.00 & $0.16^{*}$ & 0.08 & $-0.09 \dagger$ & $0.11 \dagger$ & -0.09 & -0.02 & 0.06 & 0.01 & 0.00 & -0.02 & 0.04 & -0.01 & 0.06 & -0.10 & -0.05 & 0.00 & 0.10 & 1 & \\
\hline $7^{22}$ & New CEO age & 52.18 & 3.95 & 0.02 & 0.03 & 0.01 & 0.04 & 0.06 & -0.11 & -0.04 & 0.01 & 0.00 & $0.30^{*}$ & 0.03 & -0.10 & 0.01 & 0.02 & -0.10 & 0.00 & 0.07 & 0.01 & 0.04 & 0.05 & 0.13 & 1 \\
\hline
\end{tabular}

Mean, standard deviations, and correlations are for 'first 100 days'; Significance levels at $\dagger^{\mathrm{p}}<0.1 ;{ }^{*} \mathrm{p}<0.05 ;{ }^{* *} \mathrm{p}<0.01 ;{ }^{* * *} \mathrm{p}<0.005 ;{ }^{* * * *} \mathrm{p}<0.001$ 
Table 3: Regression analysis with 3-day cumulative abnormal returns as dependent variable

\begin{tabular}{|c|c|c|c|c|c|c|c|c|c|}
\hline & $\begin{array}{l}\text { Model 1* } \\
\text { (AlI) }\end{array}$ & $\begin{array}{l}\text { Model } 1 \\
\text { (All) }\end{array}$ & $\begin{array}{c}\text { Model 2 } \uparrow \\
\text { (100 days) }\end{array}$ & $\begin{array}{c}\text { Model 3 } \uparrow \\
\text { (100 days) }\end{array}$ & $\begin{array}{l}\text { Model 4* } \\
\text { (100 days) }\end{array}$ & $\begin{array}{l}\text { Model 5* } \\
\text { (100 days) }\end{array}$ & $\begin{array}{l}\text { Model 6** } \\
\text { (100 days) }\end{array}$ & $\begin{array}{l}\text { Model 7a** } \\
\text { (100 days) }\end{array}$ & $\begin{array}{l}\text { Model 7b*** } \\
\text { (200 days) }\end{array}$ \\
\hline Constant & $0.16(0.02)$ & $0.12(0.04)$ & $0.18(0.09)$ & $0.09(0.11)$ & $0.08(0.05)$ & $0.11(0.04)$ & $0.07(0.02)$ & $0.03(0.05)$ & $0.05(0.08)$ \\
\hline \multicolumn{10}{|l|}{ Baseline hypothesis } \\
\hline Strategy presentations (H1) & $0.02 * *(0.00)$ & $0.02 *(0.00)$ & & & & & & & \\
\hline \multicolumn{10}{|l|}{ Main effect hypothesis } \\
\hline New CEOs' strategy presentations (H2) & & & $0.07 *(0.00)$ & & & & $0.04 \dagger(0.00)$ & $0.05 \dagger(0.00)$ & $0.02(0.03)$ \\
\hline \multicolumn{10}{|l|}{ Moderators } \\
\hline $\begin{array}{l}\text { Internal, non-heir apparent new CEOs' } \\
\text { strategy presentations }(\mathrm{H} 3 \mathrm{a})\end{array}$ & & & & $0.08 *(0.00)$ & & & $0.05 \dagger(0.00)$ & $0.06 \dagger(0.00)$ & $0.04(0.02)$ \\
\hline $\begin{array}{l}\text { External, within-industry new CEOs' } \\
\text { strategy presentations }(\mathrm{H} 3 \mathrm{~b})\end{array}$ & & & & & $0.11 * *(0.00)$ & & $0.08^{* *}(0.00)$ & $0.09^{* *}(0.00)$ & $0.06 *(0.00)$ \\
\hline $\begin{array}{l}\text { External, outside-of-industry new CEOs' } \\
\text { strategy presentations }(\mathrm{H} 3 \mathrm{c})\end{array}$ & & & & & & $0.14 * *(0.00)$ & $0.11 * *(0.00)$ & $0.12 * *(0.00)$ & $0.10^{* *}(0.00)$ \\
\hline \multicolumn{10}{|l|}{ Control variables } \\
\hline Low analyst following & & $0.07 *(0.00)$ & $0.06 *(0.00)$ & $0.05 *(0.00)$ & $0.07 *(0.00)$ & $0.06^{*}(0.00)$ & $0.07 *(0.00)$ & $0.08 *(0.00)$ & $0.10^{* *}(0.00)$ \\
\hline Share price volatility & & $-0.03 \dagger(0.00)$ & $-0.02(0.03)$ & $-0.01(0.05)$ & $-0.03 \dagger(0.00)$ & $-0.02(0.01)$ & $-0.04 \dagger(0.00)$ & $-0.05 \dagger(0.00)$ & $-0.07 *(0.00)$ \\
\hline Financial distress & & $-0.04 *(0.00)$ & $-0.05 *(0.00)$ & $-0.04 *(0.00)$ & $-0.05 *(0.00)$ & $-0.06 *(0.00)$ & $-0.04 *(0.00)$ & $-0.06 *(0.00)$ & $-0.10 * *(0.00)$ \\
\hline Managerial ownership & & $-0.04 \dagger(0.00)$ & $-0.02(0.01)$ & $-0.01(0.02)$ & $-0.02(0.01)$ & $-0.03 \dagger(0.00)$ & $-0.04 \dagger(0.00)$ & $-0.04 \dagger(0.00)$ & $-0.07 *(0.00)$ \\
\hline Large calls to shareholders & & $-0.03 \dagger(0.00)$ & $-0.02(0.01)$ & $-0.01(0.01)$ & $-0.03 \dagger(0.00)$ & $-0.04 \dagger(0.00)$ & $-0.03 \dagger(0.00)$ & $-0.03 \dagger(0.00)$ & $-0.05 \dagger(0.00)$ \\
\hline Regular presentations & & $0.04 \dagger(0.00)$ & $0.03 \dagger(0.00)$ & $0.02(0.02)$ & $0.06^{*}(0.00)$ & $0.05^{*}(0.00)$ & $0.04 \dagger(0.00)$ & $0.08 *(0.00)$ & $0.09^{* *}(0.00)$ \\
\hline Industry instability & & $-0.03 \dagger(0.00)$ & $-0.01(0.00)$ & $-0.03 \dagger(0.00)$ & $-0.02(0.01)$ & $-0.03 \dagger(0.00)$ & $-0.02 \dagger(0.00)$ & $-0.03 \dagger(0.00)$ & $-0.04 \uparrow(0.00)$ \\
\hline Strategic instability & & $-0.03 \dagger(0.00)$ & $-0.02(0.02)$ & $-0.04 \dagger(0.00)$ & $-0.03 \dagger(0.00)$ & $-0.04 \dagger(0.00)$ & $-0.03 \dagger(0.00)$ & $-0.05 \dagger(0.00)$ & $-0.06 *(0.00)$ \\
\hline Business complexity & & $-0.01(0.03)$ & $-0.01(0.04)$ & $-0.02(0.02)$ & $-0.02(0.03)$ & $-0.02(0.01)$ & $-0.02 \dagger(0.00)$ & $-0.03 \dagger(0.00)$ & $-0.05 *(0.00)$ \\
\hline Year dummies & Included & Included & Included & Included & Included & Included & Included & Included & Included \\
\hline R sq. & 0.12 & 0.29 & 0.16 & 0.09 & 0.10 & 0.13 & 0.34 & 0.42 & 0.39 \\
\hline Adj. R sq. & 0.10 & 0.28 & 0.15 & 0.08 & 0.09 & 0.12 & 0.32 & 0.40 & 0.38 \\
\hline RMSE & 0.34 & 0.10 & 0.22 & 0.32 & 0.28 & 0.25 & 0.09 & 0.01 & 0.02 \\
\hline
\end{tabular}

$\mathrm{N}=876 . \dagger, *$, or $* *$ indicate significance at the 10,5 , or 1 percent level, respectively, using two-tailed tests. Robust standard errors are in parentheses. Non-significant variables are included in models $1-6$ but not displayed in the table. Models $7 \mathrm{a}$ and $7 \mathrm{~b}$ exclude non-significant control variables. These are: size, litigation, contest for corporate control, new to a particular financial market, non-US, firm age, and new CEO age. 